\title{
Benkơ Samu
}

\section{Széchenyi eszméinek és cselekedeteinek korabeli erdélyi fogadtatása}

Kancák és mének magyar fülnek furcsán hangzó, idegen neveihez társítva figyel fel elổször az erdélyi újságolvasó a Széchenyi névre. A tenyészállataival díjakat nyerổ huszártiszt a lóversenyeken bizonyítja, hogy nem fóuri dilettáns, hanem lovakhoz értô szakember. Ezt hamarosan könyvvel is igazolja. Lovakrul írott munkájának példányai a Kolozsvári Református Kollégium diák-olvasóegyletének pecsétjével, illetôleg Gedõ József és Gyulai Lajos tulajdonosi bejegyzéseivel arról tanúskodnak, hogy Széchenyit, az íót, elsổ mûve megjelenésekor, azaz már 1828-ban befogadták az erdélyi olvasók, fổleg a fiatalok.

Áttekintve a Széchenyi naplóiban, levelezésében elôforduló erdélyi neveket, valósággal elcsodálkozunk, hogy az a szegényes ismeretanyag, mellyel a Wesselényi Miklóssal való találkozás, illetôleg 1821-es erdélyi útja elổtt rendelkezett, mennyire kibővült, és hogy milyen sok, több esetben milyen mély s tartós kapcsolatot épített ki erdélyi közéleti személyekkel.

A szakirodalom néhány esetben - Trócsányi Zsolt, Maller Sándor, Szilágyi Ferenc és Csetri Elek kutatásainak köszönhetôen - kimerítő képet festett Széchenyi erdélyi kapcsolatairól, így világosan áll elôttünk, hogy két földink: Wesselényi Miklós és Kőrösi Csoma Sándor milyen nagy hatással voltak rá.1 Az elsốtôl honfiúi felelôsségtudatot, az anyanyelv köteles megbecsülését, a másiktól önmegtagadást, vasakaratot és áldozatkészséget tanult.

Hogy Erdélyben kik és mit tanultak Széchenyitôl, azt már nehéz volna itt felsorolni, hiszen olyan íróktól kezdve, mint Bölöni Farkas Sándor, Újfalvi Sándor, Jósika Miklós, Kemény Zsigmond, Pálffy János, el egészen vidéken élō nevelőkig, államı és törvényhatósági tisztviselōkig, az olvasótársaságokba tömörült diákokig már-már megszámlálhatatlanok hívei.

Korszakos hatásának érzékeltetésére csak néhány bizonyságát soroljuk fel a Széchenyiéletmũ erdélyi jelenlétének.

Mellôzzük ez alkalommal a gróf Teleki Józsefhez és a báró Jósika Samuhoz fũzôdõ kapcsolatainak tárgyalását, márcsak azért is, mert az elsổel nem mint Erdély fởkormányzójával, hanem mint a Magyar Tudományos Akadémia elnökével, a másodikkal pedig nem mint Erdély bécsi udvari kancellárjával, hanem mint az önkényuralom idején a császárvárosban élố sorstársával állott közelebbi összeköttetésben, és másrészt ezeknek a különben érdekes kapcsolātoknak az ismertetése óhătatlanul szétfeszítené ennek az elōadásnak a kereteit.

A gyermekcipôjébổl lassan kinövố erdélyi hírlapirodalom munkatársai a kezdeti rövid, a lóversenyek eredményeirôl szóló hírek közlése után hamarosan elemzô írásokban is foglalkoznak Széchenyi alkotásaival. Így aztán gyors egymásutánban megjelenổ kőnyveirôl éppen úgy tudósítják az érdeklődỏket, mint azokról a vállalkozásokról, melyeknek ötlete, szervezése, irányítása az ố nevéhez kapcsolódik.

I Vö. Trócsányi Zsolt: Wesselényi Miklós. Bp. 1965; Széchenyi István-Wesselényi Miklós: Feleselö naplók. Szerk. Maller Sándor. Bp. 1986; Szilágyi Ferenc: Körösi Csoma Sándor és Széchenyi István. Magyar Nyelv 1968. 70-72; Csetri Elek: Körösi Csoma Sándor. Buk. 1984. 216-219. 
Az egyének összefogására és áldozatvállalására épülõ új polgári intézmények: kaszinók, gazdasági és mưvelổdési egyesületek Erdélyben is Széchenyi útmutatására jönnek létre. A kezdeményezôk és megvalósítók errôl gyakran tanúságot tesznek.

Az emberek egyesítésének és közös célú munkálkodásának legmegfelelôbb keretét Széchenyi a kaszinó intézményében fedezi fel. 1826 novemberében lát hozzá a pesti kaszinó elốkészítéséhez, s 1827 májusában, az elsõ pesti lóverseny alkalmával már áll az új intézmény. Híre hamar eljut vidékre, és az alapító írásaiban biztatja is egyre szélesedô olvasótáborát, hogy minél több helyen hozzák létre a „polgári erény” eme szálláshelyeit, mert „a' Casino semmi egyéb mint mủhely nevezetesb kellemek 's hasznok kiállítása végett, azaz: semmi egyéb mint eszköz, melly által magasb czélok érethetnek el".2 A cél pedig „a nemzeti értelem lehetố legnagyobb kifejtése”, egymást tisztelổ, mûvelt emberek összefogása által.

Az 1832 januárjában induló pesti lap, a Jelenkor már rendszeresen közli a híreket, hogy hol, mikor alakult kaszinó, illetổleg olvasóegylet. És mivel e lapnak volt Magyarország és Erdély címũ rovata is, természetes, hogy megtaláljuk benne az Erdélyben létesített kulturális mưhelyekre vonatkozó híreket.

Az erdélyi sajtó szintén Széchenyi szellemében sürgeti a kaszinók felállítását. A kolozsvári Nemzeti Társalkodó egyik álnévvel megjelent cikkében a városok kezdeményezố szerepét hangsúlyozza: „a' pallérozódottság és nemzetiség boldogító szelleme, $a^{\prime}$ számosabb gyülekezetek helyén, a' tudományok, mesterségek és jóllét fészkeiben, a' városokban eredve, onnan mintegy erkölcsi napból terjesztette jóltevõ világát az egész nemzetre”. Jó lenne tehát minden városban kaszinót alapítani, de jegyzi meg a cikk írója - „ezen czélra egy hely sem volna alkalmatosabb az egész országban, mint Kolo'svár". Minden jel szerint az itt létesítendõ kaszinó lenne az a hely, ahol a társadalmi összefogás ủzóbe vehetné „az elaljasodás és elkorcsosodás szellemét”, és megmutathatná ország-világ elốtt, hogy „az egyesült erố nagy siker”. ${ }^{3}$

Bölöni Farkas Sándor már évekkel e cikk megjelenése elōtt hozzálátott, hogy a „serdülổ generáció formálására” és a „meglettebb értelem érlelésére” egy olvasószobảt. illetổleg kaszinót hozzon létre Kolozsváron.4 1833-ban, a kolozsvárival szinte egy idổben kezdi el müködését a tordai, a nagyenyedi, a szilágysomlyói és a zilahi kaszinó. Az alakuló üléseken mindenütt megemlékeznek a Széchenyitôl nyert indíttatásról.

Széchenyi vetése jó termổtalajia talált. Bizonyság rá, hogy a rendốrség titkos ügynökei hamarosan jelentéseket írnak a vidéken alapított kaszinókról. A budai hadosztályparancsnok arra figyelmezteti Széchenyit, hogy minden kaszinó tövis a kormány szemében, mert azok „a liberalizmus és hungarizmus központjai”.5 A Bécsben mủködố kancelláriák pedig, mind a magyarországi, mind az erdélyi, nem késlekednek intézkedni, hogy a helyi hatóságok a legszigorúbban ellenốrizzék a kaszinók tevékenységét. ${ }^{6}$ Mindezek ellenére a kaszinók száma gyarapszik, és egyre többnek a vezetôsége lép közvetlen érintkezésbe Széchenyivel. A sajtó pedig nem szû̉nik meg rendszeresen hírt adni az országos mozgalommá terebélyesedố kaszinó-alapításokról. Az Erdélyi Híradóban 1840-ben ilyen tudósítást olvasunk: „Széchenyi István gr. folytonos munkássága legszebb

2 Széchenyi István: Világ. Pest 1831. 348

3 Hazâfi Mihál: Erdélyi Casinóról. Nemzeti Társalkodó 1832. Második félesztendỏ 113-121

4 Vö. Bölöni Farkas Sándor: Utazás Észak-Amerikában. Szerk. Benkő Samu. Buk. 1966. 23.

S Gróf Széchenyi István Naplói IV. Szerk. Viszota Gyula. Bp. 1934. 274.

6 Groff Széchenyi István írói és hírlapi vitaja Kossuth Lajossal I. Szerk. Viszota Gyula. Bp. 1927. XXVII-XXVIII. 
következményei hazánkban többi köztt a' casino-egyesületek. Nagy-Károlyban 3 év óta létezik már illy egyesület 's haszna határtalan. 187 különbözô születésũ, vallású és rangú férfi tartozik $a^{\prime}$ kitũnôbb mũveltség $e^{\prime}$ szép körébe, és egyesülten szépíti művelt társalgással életét. Ez egyesület könyvtára már is igen számos, föleg, ha tekintetbe vétetik, hogy még csak 3 év óta létezik".7

Széchenyi örömmel regisztrálja a kaszinók számának gyarapodását, hálásan nyugtázza az Erdélybôl érkezõ beszámolókat, a szervezők állhatatos buzgalmát, de figyelmezteti öket, hogy a nemzeti kultúra terjesztésében ne tủrjék meg az erổszakosságot. A nagyenyedi kaszinóhoz 1834. augusztus 10-én kelt levelében az elismerés és a féltõ aggódás hangja egyaránt megszólal: „Hogy a' Pesti Casino útján rokon hazánkban több Casinok indultak meg, azon, nem mondhatom, mennyire örvendek. Örvendeni is fogok a' léleki kifejlödésnek illy intézetein mindig, mig azokban csinosodás, nemzetiségünk erötetés [!] nélküli terjesztése, müveltebb szokások 's szebb divatok fognak uralkodni. De én leszek viszont legelsố a' Mindenható elött azok elpusztulásáért esedezni, ha azok valaha a mindent eldisztelenítō betyárságnak és sötét czimboraságnak fészkeivé aljasodhatnának le."8

Erdélyt dicséri, és józan „állhatatosságot” tanácsol itteni híveinek abban a levélben, melyet 1835. augusztus 22-én írt Teleki Domokosnak, a marosvásárhelyi kaszinó igazgatójának. Megköszöni, hogy a vásárhelyiek kaszinójuk tiszteleti tagjává vảlasztották, majd így folytatja: „Erdély tartá fenn eddig nemzetiségünk szellemét leginkább; Erdély Hölgye nem szégyenlette Magyar létét; Erdély fejté ki szebb társalkodás kellemei által eredetünk sajátságit; és annyi visszaemlékezetek varázsolnak minden hũ Magyart, ki korcs lenni nem tud, Erdély mult történetibe, hogy minden megtiszteltetés, melly onnan jổ és Magyart illet, kedvesnél csak kedvesebb lehet!"9

Az Erdélybổl Széchenyinek címzett levelek kérést és felajánlást egyaránt tartalmaznak. A Székelyudvarhelyi Református Kollégium például arra kéri, hogy könyvtárát ajándékozza meg mũveinek egy-egy példányával10, a nagyenyedi kaszinó viszont „a' magyar academia alaptôkéje nevelésére Széchenyi István másodelnök úrhoz, mint azon egyesület tiszteleti tagjához, száz váltó forintokat küldött" azzal a kéréssel, hogy azt továbbítsa a „társaság tổkéinek gyarapítására”. Köszönổ levelében Széchenyi 1837. július 17-én az adományban megtestesülō morális erôt magasztalja: „nem eléggé ismételhető igazság az, hogy csak ugy tarthat számot nemzetünk a valaha felderülhetổ dicsôség fénypontjára, ha minden tagja, kicsiny vagy nagy, tehetsége szerint jảrul a' Haza' szent oltárához, és járul tettel, sikeres tettel, mert egyedül tett ad lelket a szónak, sikertelen erôpazárlás pedig rosszabb, mint nemlét. "11

A kolozsvári kaszinó és a többi új erdélyi egyesület körül oly sokat buzgólkodó Bölöni Farkas Sándor nemcsak „szervezéstudományt” tanult Széchenyitôl, hanem irodalmi mũformát is. Belegabalyodva a romantika zseni-elméletébe, hosszú idổn át a

7 Erdélyi Hiradó (a továbbiakban: EH) 1840. július 28.

8 A Magyar Tudományos Akadémia Könyvtára Kézirattára: Széchenyi-gyưjīemény (a továbbiakban: SzGy) K 210/1. Széchenyi István leveleinek másolati könyve. 1828-1835,86, - A levelet a kaszinó következő közgyülésén, 1835. február 13-án felolvasták: a tagok „mély csenddel 's figyelemmel hallgatták a' tárgyára 's tartalmára nézve egyaránt nagy becsư levél minden szavait", megéljenezték íróját, a kaszinó "elsổ tiszteletbeli tagját s díszesító fényét". EH 1835. február 24

๑ SzGy. K 210/1. 145.

10 Széchenyi 1839. március 12-én közli a Székelyudvarhelyi Református Kollégiummal, hogy teljesíti a kérést és küldi a kért könyveket. SzGy. K 200/2.

11 SzGy. K 197/38. Vö. EH. 1837. július 15. 
tehetségével semmiképpen sem konvergáló költôi müfajokban próbálja Schillert vagy még inkább Kazinczyt követni, míg végre Széchenyi értekezổ prózájában megtalálja azt a felszabadító példát, mely élményeihez igazítva segítségére lesz abban, hogy formába öntse remek útirajzát és naplóját. Olyan könyvet ír, melyet Széchenyi „legkedvesebb kincsei közé számlál"12.

Bölöni Farkas kezdeményezése nyomán a kolozsvári kaszinó körébốl nố ki a Vasárnapi Újság címũ népszerũ lap is, mely 1834 és 1848 között, Brassai Sámuel szerkesztésében sokat tesz a kimũvelt emberfớk számának gyarapítása érdekében, s ezenközben hũségesen terjeszti olvasói körében Széchenyi eszméit.

Nem véletlen, hogy ahol Erdélyben élénk kaszinói élet bontakozott ki, ott a törvényhatósági gyưlések szónokai is egyre gyakrabban veszik szájukra a Széchenyi megfogalmazta reformeszméket, és gondolataira mindmegannyi sarkigazságra hivatkoznak. A városi és vármegyei közgyüléseken egymás után hangzanak el arra vonatkozó javaslatok, hogy valamilyen formában adják nyilvános jelét hálájuknak és Széchenyihez való ragaszkodásuknak. A városok polgárjoggal tisztelik meg, a vármegyék táblabírájuknak választják, másutt életnagyságú képe megfestését határozzák el - így Bihar megyében —, utóbbihoz Széchenyi úgy járul hozzá, ha a kép megfestését Barabás Miklósra bízzák.13

A sokféle kitüntetés között a legszellemesebbnek Alsó-Fejér vármegye ötlete bizonyult: ök „a' derék hazafi grófot” aranytollal „határozták megtisztelni”. Az átadás — olvashatta a kor újságelöfizetổje - „szerény, kisded, de annál ổszintébb jelentésủ innepséggel történt meg august. 24ikén a' nemes gróf ur szállásán Pesten".14 Gyulafehérvári Farkas Sándor's és Horváth Ferenc két erdélyi ifjú kíséretében adta át a megye ajándékát. A bensốséges családi ünnepélyen Farkas Sándor felköszöntổ beszédében - többek között - elmondta, hogy a Széchenyi gyújtotta fáklyának a fénye az ổ szũkebb hazájába is beszüremkedett. A beszédböl kitetszően a derék nagyenyedi követek ellenzéki megbízóiktól azt is feladatul kapták, hogy Széchenyit a perbe fogott Wesselényi Miklós melletti kiállásra ösztönözzék.16

Széchenyi Pozsonyból 1835. november 9-én keltezett, terjedelmes levélben köszöni meg a tollat és az üdvözlố szavakat, anélkül hogy Wesselényi nevét említené, de mindenképpen az ellene indított hajszára utalva, azzal biztatja „a szomorú állapotban” élö erdélyieket, hogy a „Szent Igazság” elöbb-utóbb diadalmaskodik. No de idézzük kissé részletesebben a nagyenyediekhez szóló intelmeket: „A' Magyarnak semmi idổben sem volt nagyobb vagy legalább károsb ellensége mint önmaga. 'S ezen boldogtalan öngyilkolási szellem, mely évrajzink minden lapjait diszteleníti, sehol egyebütt, mint Nemzetünk tenger-hiuságában 's korlátot nem ismerő kevélységében vette eredetét. Mindenki mindenben elsố 's vezetổ vágyott lenni, igaz szó sérté, hizelgés könnyen bilincsélé; - mibül mind azon határtalan rossz áradott szegény hazánkra szünetlen, mit a' megbántott hiuság, bosszut-szomjazó agyarkodás 's rokon vér utáni esengésnek poklai az emberi nem lealacsonyitására, megsemmisítésére csak forralhatnak.

12 Bölöni Farkashoz intézett, 1834. szeptember 10-én Orsovän kelt levelét 1. Gróf Szécherryi István levelei I. Szerk. Majláth Béla. Bp. 1889. 498-499.

13 Széchenyi István levele Bihar vármegye Rendjeihez. EH 1836. május 7.

14 EH. 1835. október 3.

15 Jeles történeti munkák szerzöinél is elöfordul, hogy Gyulafehérvári Farkas Sándort. a nagyenyedi kaszinó alapítóját összetévesztik Bölöni Farkas Sándorral, az észak-amerikai utazóval. E felcserélés oka éppen az, hogy mindketten hư emberei voltak Széchenyinek, aki öket emlegetve, nem minden esetben tünteti fel elớnevüket. Vö. Erdély törnénete III. Szerk. Szász Zoltán. Bp. 1986. 1268.

16 Paszlavszky Sándor: Gr. Széchenyi István aranytolla. Hazánk. Történelmi Közlöny X(1888). 78-79. 
Vegyük például a' Multat, 's tanuljuk meg elvégre az Önmegtagadást, a polgári erények $\mathrm{e}^{\prime}$ legnagyobbikát; 's Hazánk boldogabb sorsa biztos. Mert önmegtagadás türödelmet szül, nagyobb tulajdonoknak irigyül utat nem zár, 's örömit a' közjóban, közszerencsében, 's nem személyt-érintő diczéretben 's jutalomban leli. 'S mi legfớbb pánczélul szolgál a' nemzetiség mind azon megtámadásai ellen, millyeket a' Világ nemzet-nélküli selejtesei minden idổben 's szünet nélkül koholtak az emberiség lelkesb része ellen." 17

Széchenyi mũveirôl Erdélyben az elsō komoly, rész'etes cikket (neve feltüntetése nélkül) Brassai Sámuel írta. Nevét a $\mathrm{W}$ betư mőgé rejtổ szemleíró azzal kezdi - különben magának is elsô, nyomtatásban megjelent - polémikus hangvételữ cikkét, hogy a Hitel és a Világ megjelenése után „méltatlanul gáncsoskodók” léptek a színre. A bírálók súlyos hibájául rója fel vakságukat: nem veszik észre, hogy. Széchenyi két könyvével egy új tudomány jelent meg a magyar mũvelódési életben: „A' *Hitel* 's *Világ* azon csak kevés tizedek elôtt szinte ujonnan teremtett tudomány némely ágait világítják, melynek politica oeconomia a' neve, 's mivel bennek semmit sem találhatni a' mi ezen tudomány Quesnaytől Ricardoig közönségesen elesmert legjózanabb elveivel ne egyeznék, sốt ezen elveknek Magyarországra alkalmaztatása is éles szemet 's gyakorlott itélöképességet láttat, méltán következtetjük, hogy Széchenyit e' tárgyban Mesternek kell esmernünk." A cikk írója kellố gúnnyal állapítja meg, hogy Széchenyi és bírálói között nagyságrendbeli különbség van: „Valóban bosszankodás - felhevült bosszankodás fog-el, ha megtekintem ezek a' sas hátán felemelkedett ökörszemek miként akarják leczkézni mestereket, 's egyfelöl nagy alázatossággal 's complimentekkel melléje lépvén, másfelöl miként próbálnak lehúzni róla minden írói érdemet." $\mathrm{S}$ miután a bírálók mondvacsinált gáncsait visszautasítja, Brassai így összegzi mondandóját: „berekesztésül kimondom saját itéletemet, hogy Gróf Szécseny [!] Istvánt egy tárgyához jól értō, méj bélátással bíró, szellemteli eredeti írónak tartom..."18

Lassan Erdélyben is hírértéke lesz mindennek, ami Széchenyi körül történik. Megírják, hogy állóhidat szándékszik építeni Buda és Pest között19, Londonban hatalmas pénzért "gổzerổmíveket 's más nemư mívszereket vásárlott össze” a hạjózás „könnyítése és bátorságossá tétele" érdekében ${ }^{0}$, a Dunán és a Tiszán tett hajóútiaival új irányt kíván szabni a folyamhajózásnak. ${ }^{21} \mathrm{De}$ az erdélyi újságokban helyet kap az ittenieknek az a reménysége is, hogy fertelmesen rossz útjaik javítására, illetôleg újaknak az építésére támogatást kaphatnak tổle.22 A vasút dolgában szintén belé vetik bizodalmukat. 1848-ban akadnak Kolozsváron olyan választópolgárok, akik azért javasolják Széchenyit országgyưlési képviselổnek, „mivel Kolozsvárnak vas-útpályára van szüksége 's ennek kivihetése leginkább a' tisztelt gróf úrtól függ”. Brassai Sámuel lapja, a Vasárnapi Újság ízléstelennek tartja a fenti indoklást, mert az azt feltételezi, hogy Széchenyit le lehet kötelezni egy képviselõi mandátummal, hogy „elôleges felpénzeléssel lehet kivívni” nála valamilyen ügy sikerét.23

17 SzGy. K 210/1. 177

18 W: Gróf Szécheny [!] István és Birálóji. Nemzeti Társalkodó 1832. Elsô féleszlendö 273-282. 289-295 és 305-319. Vö. Mikó Imre: Az wtolsó erdélyi polihisztor. Buk. 1971 189-190.

19 EH. 1833 . június 25.

20 EH. 1834. május 6.

21 EH. 1833. szeptember 24., 1834. december 13., 1836. november 19

22 Pálffy János: Viszhang [!]. EH. 1842. május 10.

23 . Több kolozsvári választók" aláírással megjelent nyilatkozat. Vasárnapi Ưiság 1848 . június 19. 
Széchenyi politikai vitáinak híre természetesen Erdélybe is eljutott. A magyar mưvelôdési életben már korábban is voltak késhegyre menõ polémiák - gondoljunk csak a hitvitákra vagy a nyelvújítás körüli tollcsatákra -, de a vitáknak széles körũ olvasóközönsége csak a Széchenyi-Dessewffy, majd a Széchenyi-Kossuth szellemi párviadal nyomán támadt. Üjságcikkek, levélbeli reagálások bizonyítják, hogy az erdélyi tollforgatóknak az a liberális csoportja, mely az Erdélyi Híradó körül tömörült, a Hitel megjelenése után támadt vitában egyértelmũen annak szerzõje mellett foglalt állást, a Kossuthtal viaskodó Széchenyivel azonban már nem ért mindenben egyet. Wesselényi különösen sokat tesz annak érdekében, hogy az erdélyi publicisztika Kossuth mögé sorakozzék fel. 24

Mindjárt $A$ Kelet népe megjelenése utản Katona Miklós - kvietált katonatiszt, Wesselényi Miklós híve - arról írt, hogy a könyv nem tudta kikezdeni Kossuth Lajos növekvố népszerũségét: "A' sokszor emlegetett, aggodalommal várt »Kelet népe* megjelenék, 's minden, ki ösmerve szerzôje nagy nevét, gyanítva a' hon legkedveltebb hírlapja jeles szerkesztôje elleni czélzatát, olly részvéttel ragadta el, hogy elsõ kiadása, mint értésemre esett, mielôtt a' távolabb megyeiek megkaphaták, már el volt kelve... De sokaknak, szerfelett sokaknak nem tetszhetett, hol Kossuth Lajosra alkalmaztatja okoskodásait; hol a' revolutio syllogizmusát emlegeti; hol Kossuth módját Mirabeau, Danton, Robespierréhez, 'a több másokéhoz hasonlítja." A Széchenyivel egyet nem értôk számosan vannak, s nyilvánosan is bizonyságát adják, hogy a megtámadt Kossuth pártján állanak. „Ezek közül egy számos csoport - folytatja írását Katona Miklós - június 27kén Kossuth Lajost számtalan égổ szövétnek fényénél éjzenével tisztelé meg bizonyítékul: mennyire vonta el e' röpirat tôle a' közkedvességet." 25

Az Erdélyi Híradó többször is visszatér a vitára. Kossuth mellé állva is hangsúlyozza Széchenyi „polgári erényeit”, és leszögezi: „meg vagyunk gyôzôdve arról, hogy páratlan hazafi-érdemeinek súlyát ha a' Kelet Népe nem könyíté is a' mérlegben, de terhelni sem fogja egykor a' történészet bírói széke elött".:-

A hosszan tartó vitában egy $X$ aláírású cikk szerzõje ugyancsak Kossuthnak ad igazat, és helyteleníti Széchenyi harcmodorát. E vita már nem elveket tisztáz, hanem ártalmára van a közügynek - olvassuk a cikkben, mely így folytatódik: „Annyi igaz, hogy ha van tusa, melly méltán követelheti, hogy vége bevárassék, mielốtt a' dolog érdemében bírálólag szólunk, a' Széchenyi-Kossuth pör az... A' nemes gróf elbizakodva kissé a' varázs-eröben, mellyet a' magyar szívére olly rég gyakorol, hamis játékot ũz $\mathrm{e}^{\prime}$ hatalommal..."27

A világéletben okos kompromisszumokra törekvõ Méhes Sámuelnek azonban arra is van gondja, hogy lapja ne kötelezze el magát egyoldalúan a pesti sajtóban folyó vitában, ezért a Kossuthot támogató cikkek mellett gyakran közöl olyan írásokat is, melyekbôl kitũnik változatlan tisztelete Széchenyi iránt. Így Hírlapvilág rovatában elismeréssel emlékezik meg Széchenyinek a Jelenkor 1845/36. számában napvilágot látott Általános nézetek c. cikkérö̉, melyben arról ír, hogy nem lehet örökösen csak a bajokat emlegetni, a hibákat ostorozni; alkalmat kell találni az eredmények számbavételére is. A cikkíró örvend, hogy az Erdélyi Híradó és Széchenyi egy véleményen van: „Mi eddig sem tartozánk azok sorába, kik untalan jajveszékelnek a' haza hanyatlásán, 's most annyival

24 Trócsányi Zsolt: i.m. 118-121, 474-484.

${ }^{25}$ Katona Miklós: „A' kelet népe" miauti mozgalmak. EH. 1841. augusztus 13.

26 EH. 1842. január 14.

27 X: Testvérhoni viszályok. EH. 1843. február 21. 
örömestebb osztozunk a' t. szerzō e' nézetében, mivel épen csekély magunk, e' rovat alatt mondottuk volt egykor, a' Gróf egy, egészen más hangulatú czikkére, miként a' szunyadó erổket tevékenységre ébreszteni, talán czélszerủbb eszköz ollykor a' siker fölmutatása is, mint mindig csak a' hátramaradás, nemzeti inség kiáltó színekkeli rajzolása." 28

A vitázó felek közötti kiegyenlítôdés keresése, a közös ügyet mindenek fölé helyezỏ magatartás sugallta azokat a sorokat is, melyek a Kolozsvári napló rovatban beszámoltak Deák Ferenc és Vörösmarty Mihály erdélyi útjáról. A köztiszteletnek örvendổ államférfi és a költô Zsibóról érkezett Kolozsvárra. Zsibóra „egy hona fölött már csak lelki szemeivel virrasztó derék hazánkfia 's barátuk látogatására mentek volt". Minden újságolvasó tudta, hogy a fogságban megvakult Wesselényi Miklósnak szólt a látogatás. Kolozsvár közönsége kitörổ lelkesedéssel fogadta a vendégeket; Kemény Sámuel „barátságos estebédre” hívta meg ôket, s miközben a pesti hírlapokban kemény csata dúlt a közéleti férfiak között, a kolozsvári vacsorán „vidám poharakat” ürítettek Deák Ferenc, Vörösmarty Mihály, Teleki József, Széchenyi István és Kossuth Lajos egészségére. ${ }^{9}$ Némi bizonysága ez annak, hogy Kolozsvár tud - vagy legalábbis volt idổ, amikor tudott - eszméket, érdekeket egyeztetni.

Abban a hírlapi vitában, amelyet az 1841-ben megjelent A Kelet népe és az 1842-ben elhangzott Akadémiai beszéd váltott $\mathrm{ki}$, központi helye volt a nemzeti-nemzetiségi kérdésnek; Széchenyi mindkét helyen félreérthetetlenül elutasította az agressziv nacionalizmust, és mindenkire kiterjedổ nyelvi kíméletet sürgetett. Természetes, hogy a vitának erre a mozzanatára felfigyelt az erdélyi szász és román sajtó is.

Erdély nem magyar értelmiségi férfiai között kétségtelenül George Baritra gyakorolta Széchenyi a legmélyebb hatást. Föművében, a Părti alese din istoria Transilvaniei c. könyvében ismerteti Széchenyi életrajzát, szól külföldi utazásairól, és reformterveit felsorakoztatva különösen kiemeli, hogy olyan törvények alkotását sürgette, melyek az élet minden területén meghozzák a közboldogságot.30 Egyik legjobb ismerōje egyenesen szemére hányja Barił̧nak, hogy „túlzó apológiával veszi számba Széchenyi társadalompolitikai, gazdasági, mưvelổdési eszméit és haladó kezdeményezéseit, amikor bizonyságot tesz arról, hogy ifjúkorában az ő írásainak a hatása alá került". ${ }^{31}$

Barił̧ újságjait (kettổ is volt) lapozgatva megbizonyosodhatunk, hogy Széchenyi neve minduntalan felbukkan a hasábokon, hol a hírekben, hol azokban a cikkekben, melyek hivatkoznak reá, illetôleg idéznek tôle, de az is elöfordul, hogy terjedelmesebb Széchenyi-szövegek román fordítását teszi közzé a szerkesztō. A Foaie pentru minte, inimă şi literatură 1841 ốszén Széchenvi István grớf ür polirikai hirvallása címmel szemelvényeket közöl A Kelet népébôl.

A közzétett Széchenyi-szöveghez lapalji jegyzetben Barit kétszer is magyarázatot füz. Elổször annál a mondatnál, ahol azt írja Széchenyi: „a rám vett adónak mire fordítását nem kívánom ellenốrizni mindaddig, mig a polgár és pór illyesbül ki van szoríva" (Sz. I. kiemelése), Bariţ csillag alatt megjegyzi: „Íme, hogy beszél Magyarország legtöbbre becsült fôura! S mi több! Ez utóbbi könyvét már senki sem égeti el. Szerk." És majd Széchenyinek ennél a mondatánál: „...szünjék meg végkép azon botránkoztató különbség, melly szerint éppen az legyeztetik egyben, mi irgalmatlanul sủjtatik másban: de józan

28 EH. 1845. május 13.

29 EH. 1845. május 20.

30 George Barit: Părti alese din istona Transilvaniei I. Sibiu 1889. 564-574.

31 George Em. Marica: Studii de istoria și sociologia culturii române ardelene din secolul al XIX-lea II Cluj-Napoca 1978. 312 . 
irányba hozassék más részrül azon puhaszívũ ábrándozás is, mintha ki lehetne küszöbölni közülünk minden állati büntetést, márul holnapra, és mielött köznevelés kiemelné legalább a' nagyobb részt az állati tengés köreibül" - Barif ismét csillagot tesz és a lap alján ezt írja: „Halljátok, halljátok!" 32

Bariţ éveken keresztül figyelemmel kísérte a Széchenyi és Kossuth között támadt hírlapi vitát is. Amikor errôl a Gazeta de Transilvania 1843-as évfolyamának elsō számában ismertetést ír, arról is szól, hogy a román olvasóknak föltétlenül szükségük van kitekintésre, arra, hogy lássák: mi történik körülöttük. „Nehéz idôkben élünk, véreim írja -; a' körülmények nagyon szorosan parancsolják, mikép házunk álmatlan éberséggeli ổrzése mellett vessünk egy komoly pillanatot a' szomszédokra is mindenfelé." 33

Barit a forradalom és szabadságharc bukását követő időkben is elismerően nyilatkozik Széchenyirôl, és halálakor életmưve egészének maradandóságát hangsủlyozza. ${ }^{34}$

Széchenyi erdélyi megotthonosodásának egyik beszédes példája mutatkozik meg abban, ahogy évek teltével ổ Nagyenyedet értékeli.

A Széchenyi-naplót fordító költõ, Jékely Zoltán (a nagyenyedi Bethlen Kollégium egykori tanárának, Aprily Lajosnak a fia) mélységes fájdalommal vette tudomásul, hogy 1821 nyarán Széchenyi úgy megy keresztül Nagyenyeden, az ô szülōvárosán, hogy észre sem veszi a kollégiumot, annak tudós tanárait, a sok diákot, csak a város piszkos kaszárnyájáról s a benne zsörtölôdő huszár óbesterrôl tesz említést. ${ }^{35}$ Évek múltával, amikor Széchenyi az erdélyi kultúrát már jobban ismeri, e városban is többet lát. mint egy huszárezred szálláshelyét. 1840. december 10-én Szász Károlyhoz mint ,igen tisztelt barátjához" intézett levelébôl arról értesülünk, hogy az enyedi professzor sorsa éppen úgy foglalkoztatja, mint a diákok jövője. A "gyönyörũ ifjak, teli isteni szikrával" - íria egy felállítandó mủegyetemen képezhetnék magukat "jó gazdává, erômüvésszé, gyárossá", s örülne, ha ezt a tervezett intézetet Szász Károlyra bízhatná. ${ }^{36}$

Szász Károlyból ugyan nem lett tanár az óhajtott „központi polytechnikumban.” de kettôjük szivélyes viszonya a késóbbiekben is fennmaradt. 1848 nyarán, amikor Erdély súlyos, megoldatlan kérdései láttán többen Széchenyi személyes megjelenésétől várnak megoldást, Szász Károly is levélben fordul hozzá. Ebben elpanaszolia Erdély „naponként aggasztóbb” állapotát, és a „pusztító vész” elhárításának egyetlen módját abban látja, hogy István nádor és Széchenyi együtt tegyen legalább egy hétnapos körutat Erdélyben, felkeresve feltétlenül Kolozsvárt, Nagyszebent és a Székelyföldet. Egy ilyen körút „egy egész ármadának megielenésénél üdvösebb, a' merénylöket visszarettentō, az ingerülteket lecsillapító, a' tétleneket munkásságba hozó" lenne. ${ }^{37}$

Ezekben a baljóslatú napokban érdekes módon, több irányból is Széchenyi felé irányul az erdélyiek bizalma. Wesselényi Miklós 1848. július 12-én Bethlen Jánossal közös felterjesztésben fordul a magyar miniszterelnökhöz; ebben azt javasolják, hogy a kamarilla és bürokrácia veszélyes intrikáinak megakadályozására Széchenyi személyében

32 Credeul politicesc a domnului graf Stefan Seceni. Foaie pentru minte, inimă şi literatură 1841. októher 5. Vö. Kovács József-Kovács Ferenc: Két évszázad kortársa George Barifiur. Kolozsvảr-Napoua 1984. 56-58.

33 Gazeta de Transilvania 1843. január 4. - A cikk magyar fordílása EH. 1843, január 31.

34 Gazeta de Transilvania 1858. szeptember 18. és 25. - Memoria contelui Stefan Sechenyi. Uo. 1860. április 14

35 Jékely Zoltán: Tînödések és észrevételek Széchenyi naplójának fordỉása közben. = A Bárány Vére. Bp. $1981,142-153$.

36 A Szász Károlyhoz intézett, Pesten, 1840. december 14-én kelt levelet 1. Benkô Samu: Örszavak. Buk. 1984. 236-238.

37 Szász Károly Kolozsvárról, 1848. június 16-án keltezett levele: SzGy. K. 208/140 
küldjenek királyi biztost Erdélybe.38 Négy nap múlva magát Széchenyit unszolja Wesselényi, hogy neveztesse ki magát Erdély királyi biztosává és sürgōsen utazzék Kolozsvárra. ${ }^{39}$

Széchenyi erdélyi tekintélyének súlyát jelzi, hogy az említett magyar közéleti férfiak próbálkozásaival egy idôben a nagyszebeni ortodox püspök, a balázsfalvi nemzeti gyũlésen a Román Nemzeti Komité társelnökévé választott Andrei Şaguna többször is arra kéri a magyar közlekedésügyi minisztert, hogy vállalja el a királyi biztosságot, siessen Erdélybe, már csak azért is, mert „egy ember sem olyan népszerũ Erdélyben”, mint ô. „Nos igen - válaszolta naplója szerint Şagunának a gróf - ha megyek, önnek kell a vezetốmnek lennie." 40 Két nap múlva visszatérve az ügyre ezt jegyzi fel: „Hajlandó vagyok Erdélybe menni, de csak Şagunával." 41

A hívó, már-már könyörgô levelek és szóbeli biztatások végül is hiábavalóaknak bizonyulnak: Széchenyi nem szánja el magát az erdélyi útra. De naplóbeli feljegyzései szerint egyelổe még figyel arra, hogy mi történik Erdélyben. Az elhatalmasadó idegbetegsége elsô jelei s a mardosó önvád kóros fellépései is némileg Erdély felé utalnak. A kolozsvári Méhes Sámuelt idézve, 1848. július 17-én ezt veti oda naplójában: „Méhes dicsér a Hitelemért. *Ha ez nem iratik, mindez nem történik!* — Én — miközben ő átdöfi a lelkemet: *Tán jobb lett volna azt soha nem írni! «"42

Miniszterként naponta sok erdélyivel találkozik. A minisztertanács ülésein rendszeresen jelen van a belügyi államtitkár, Kemény Dénes is, a sokat próbált erdélyi ellenzéki politikus, aki maga is bôven merített Széchenyi mũveibõl, azokat továbbfejlesztve és az erdélyi viszonyokra alkalmazva írta meg Érdekegység címũ munkáját az alkotmányosság korszerũ ismérveirôl, a legsürgõsebb reformokról, köztük az örökváltságról és a közteherviselésrôl. Erdélyben nem tudott megbirkózni a cenzúra „nyũgével” és „szeszélyével”; végül is megpróbálta könyve kinyomtatását Magyarországon engedélyeztetni, s ehhez kért levélben segítséget Széchenyitổ. 43

A független magyar kormány ülésein Kemény Dénes ritkán szólalt meg, de élénken figyelt, és benyomásairól feljegyzéseket készített. Ezekben megállapította, hogy „az egész minisztérium csupa bölcs és jeles státusférfiakból áll, hanem praktikus embert csak kettổt ismerek köztük. Áz egyik Széchenyi, a másik Deák". Majd így folytatja: „Széchenyi egészen csodálatos állást foglalt el a minisztériumban. Képzelj magadnak egy kapitányt, a kit schwadronjával kiküldenek egy "verlorener» Postra. - A kapitány tudja, hogy nincs menekvés, de a legénységnek jó arczot mutat, $s$ úgy tesz, mintha minden rendben volna." 44

Mendemondák és szakszerũ vizsgálódások jócskán emésztették a tintát Széchenyi önsorvasztó képzelgései, egyre súlyosodó betegsége titkainak feszegetése körül. A kóros idegrendszeri elváltozásnak döbbenetes bizonyítéka van: Széchenyi írásképe 1848 nyarának végén radikálisan megváltozott; a betegség kíméletlenül elrontotta íráskészségét. Éppen e jelenséghez kapcsolódva izgalmas párhuzamként merült fel bennem a félelmetesen

\footnotetext{
38 Trócsányi Zsolt: i.m. 541 .

39 Spira György: 1848 Széchenyije és Széchenyi 1848-a. Bp. 1964. 237.

$40 \mathrm{Gr}$. Széchenyi István döblingi irodalmi hagyatéka 1. Szerk. Kảrolyi Ärpád. Bp. 1921. 339

41 Uo. 341 .

42 Uo. $353-354$.

43 Kemény Dénes 1847, június 25-én Nagyenyedröl keletkezett levele: SzGy. K $205 / 113$.

44 Ifj. gróf Bethlen Miklós: Múlt és jelen. Régi levelek és divatos erkölcsök. Bp. E.n. 23-25.
} 
hasonló írású Bolyai János sorsa s a Széchenyi-Bolyai viszony közelebbi vizsgálatának gondolata. 45

Közvetlen kapcsolat kettôjük között nem volt, de Széchenyi mint akadémiai elnök bizonyára hallott tagságáról, Bolyai Farkasról. Irományai között én csak egyetlen helyen láttam leírva a marosvásárhelyi matematikus nevét, mégpedig abban az elég gyakran idézett levélben. melyet 1850. szeptember 7-én a döblingi szanatóriumból küldött Tasner Antalnak, és amely így kezdõdik: „Ma indulok pokolba! - Én vagyok azon ármány fía, ki bûneim súlya miatt már 1811-ben elkárhozva, mint ördög szolgája betủ szerint eladtam a magyart a rossz Istenének." A dúlt elme ebben a levélben németre váltva a szót, számba veszi a magyar közélet és magyar mũvelôdés korabeli szereplöit, és köztük említi a tudósokat is: „Bolay [!], Stoffer, Kovács Lai, Helmeczy, Döbrentey, Vásárhelyi... wo sind solche Leute in der Welt." 46

A Bolyai-kéziratokban az apánál és a fiúnál egyaránt többször felbukkan Széchenyi neve. Egy levélben Bolyai Farkas arra hívja fel fia figyelmét, hogy Széchenyinek nagy mũvelõdési tervei vannak, és valóra váltásuk érdekében pénzt szerez kölcsön az országnak. Nyilván az Adó és Két garas címũ mũben foglaltak jutottak a tudós tanár füléhez. ${ }^{47}$ Bolyai János kézirataiból azt a részt emelném ki, ahol Széchenyire hivatkozva bírálja II. József reformjait. A Sziszüphosz módjára .maga elôtt évtizedeken át gondolatsziklákat görgetố Bolyai János többszōr szembenéz a világboldogító szándékok balsikerével, és ennek okát „valamennyi eddig Világ-reformátor" "hebehurgyaságában” fedezi fel. Azt veti szemükre, hogy elmulasztották a „vetés elốtti illó szántást”. Így kerül szõnyegre II. József reformjainak kudarca: „...mint már, úgy tetszik, a derék Széchenyi István is megjegyzette”, a legnagyobb hibát a császár azzal követte el, hogy „ön-fejüleg, meg-kérdezésünk, a tanácskozásbani részvétünk nélkül, tehát erõszakoson akart boldogítani". 48

További Széchenyire utaló idézetek felsorakoztatása helyett célszerübbnek tartom annak a kiemelését, hogy Bolyai János és Széchenyi István gondolkodása mechanizmusában markáns rokon vonások fedezhetơk fel. Mind a ketten a matematikában látták azt a tudományt, mely módszertani kiindulópontja kell hogy legyen a szabatos fogalomalkotásnak. Széchenyi is éppen úgy a "mathesisi szigor”-nak a híve, mint Bolyai János. A Stadiumból idézett alábbi mondatát akár az erdélyi matematikus is írhatta volna: „A' hideg számolás, mert csak az vezet a' mathesisnek isteni utján a' valóhoz, legyen egyedüli kalauzunk." 49 A matematikai szemléletmódnak érdekes példáját idézhetjük a Hitelbôl is. Abban a gondolatmenetben, ahol Széchenyi arra a kérdésre válaszol, hogy „mit kell tenni 's min kell kezdeni”, mindjárt az elején ezt a figyelemre méltó megjegyzést teszi: „alap nélkül tartósan nem állhat semmi 's kizárólag csak azon tárgyat birhatjuk igazi sikerre, mellyet természetes vagy matematikai renddel - $a^{\prime}$ mi nálam egy - kezdünk 's folytatunk".so Láthatóan a természetes rend Széchenyi gondolkodási rendszerében azonos a matematikai renddel!

A kor központi kérdése a nyelv; a XIX. század elsổ felében nincs jelentổs magyar író és tudós, aki el ne töprengene a nemzeti nyelv jelenén - jövôjén. Széchenyinél és Bolyai

45 Vö. Benkỏ Samu: Széchenyi közjóra való törekedései. = Órszavak. Buk. 1984. 218-221.

46 Gróf Széchenyi Istuán levelei III. Szerk. Majláth Bẻla. Bp. 1891. 630-636.

47 Nagy Ferenc: Széchenyi és Bolyai. Rubicon 1991. 5. sz. 17.

48 Bolyai János kéziratai a marosvásárhelyi Teleki-Bolyai Könyvtárban, 638.

49 Széchenyi István: Stadium. Lipcse 1833. 42.

so Széchenyi István: Hitel. Pest 1830. 153. 
Jánosnál az a közös ezekben a töprengésekben, hogy mindketten ismételten a nyelv és a matematika összefüggéseit firtatják. A pontos és félreérthetetlen információ-rögzítés izgatta mindkettôjüket, az, hogy például a mondat annyira egyértelmứ legyen, mint mondjuk az egyenlet. Széchenyi 1826-ban ezeket jegyzi fel: „A nyelvnek tökéletlenségéből fakad a legtöbb baj és a legnagyobb időpazarlás a világon. - Nincs olyan szó, mely más szavakkal összetéve vagy akár magában is, jelentését ne változtatná. Innen minden per, homályos törvények etc. - Érzem, fel fognak még találni valami módot számokkal írni úgy, hogy amit leírtak, örökre és minden fogalomra mathematikailag mindig azonos marad."sı A matematikai szabatosságú nyelv igénye melynek megteremtése sürgős nemzeti feladat - felbukkan az 1842-es akadémiai beszédben is. Egybegyült tudóstársaihoz így szól Széchenyi: „...egyedül csak elöleges, szorosan meghatárzott definitiók következésében lehet nagyobb szövevényü fejtegetésekés vitatkozásokban, aránylag könnyen vagy csak általjában is, czélhoz jutni, ti. az igazságot teljes világba helyezni, 's ekkép rábeszélnı 's gyôzni. Mi okbul nemcsak látszólag, de valósággal sem lehet nemzetnek sürgetôbb és komolyabb tenni-valója, mint nyelvét lehetổleg közel vinni $\mathrm{a}^{\prime}$ szoros tudományok szabatosságához; mert csak olly nyelvvel, melly ehhez leginkább közelít, lehet aránylag legtöbbet legszaporábban sajảt érdeke körül felvilágosítni ..." 52

Senki elổt nem volt titok Erdélyben, hogy már a reformkorban kezdeményezett, majd 1859-ben megalakult és munkásságát nagy lendülettel elkezdổ Erdélyi Múzeum-Egyesület létrejöttében is elhatározó szerepe volt Széchenyi „aluszékonyokat felrázó" mũvelôdésserkentô ösztönzésének. Szabó Sámuel naplójából értesülünk arról, hogy az Erdélyi Múzeum-Egyesület elsô közgyũlése napján, az ünnepi lakomán az alapító tagok errôl nem feledkeztek meg: éljenzéssel fogadták a bejelentést, hogy Széchenyi a kétségbeesésbổl származó nagy betegségébổl „ủjra éledni kezd”, és azt kívánták neki, hogy „napról napra erôsödjék, hogy élhessen soká”. A beszámoló szerint „Brassai Sámuel e megemlékezés táviratoztatását kívánja. (Megtörtént)"s3

Ha körülnézünk azok között az erdélyiek között, akik különös vonzalommal viseltettek Széchenyi iránt, szembetửnik, hogy milyen sok köztük a természettudományokban jártas, közgazdaságtanilag iskolázott, egyszóval a "szoros tudományok szabatosságával” gondolkodó egyén. Ezek közül most még kettổoől: Kemény Zsigmondról és Teleki Domokosról ejtünk néhány szót.

A bécsi egyetem orvosi fakultásán anatómiát és patológiát hallgató Kemény Zsigmond könyvespolcán ott sorakoznak a közgazdaságtudomány legfrissebb nyugat-európai termékei, és elsô könyvét, a Korteskedés és ellenszerei cỉmủ politikai esszéjét egyik kortársa „az álladalmat atomjáig boncoló munkának” nevezte. 54 Nem véletlen, hogy a könyvet olvasva Széchenyi azonnal felismeri szerzőjében a maga emberét, és Tasner

S1 Széchenyi István: Napló. Szerk. Oltványi Ambrus. Bp. 1978. 477. Jékely Zoltán szép fordítása mellett álljon itt az eredeti német szöveg is: . Aus der Unvollkommenheit der Sprachen entstehet das meiste Übel, und der grösste Zeit Verlust auf der Welt. - Es ist kein Wort. das in der Zusammensetzung mit andern Wörtern. oder auch genz allein - seinen Sinn nicht verändert - Daher - alle Processe - undeutliche Gezetze ect. Ich fühle dass man noch eine Art erfinden wird durch Nummern zu Schreiben - so dass das Geschriebene ewig und für alle Begriffe matematisch stets die selbe bleiben wird." Gróf Széchenyi István Naplói III. Szerk. Viszota Gyula. Bp. 1932. 75 .

\$2 Széchenyi-Kossuth idézett hírlapi vitája 1. 160.

53 Szabó Péter: Az EME elsõ ünnepi lakomája. - Emlékkönyv az Erdélyi Mủzeum-Egyesület félszázados iunnepére. 1859-1909. Szerk. Erdélyi Pál. Kvár 1909-1942. 89.

54 Zeyk József: Känyvismertetés. EH. 1843. 613. 
Antaltól nyomban érdeklődik is utána: „ugyan kicsoda, micsoda?"ss Szemét ettől fogva rajta tartja, s 1846-ban meghívja, hogy kísérje el tiszai szemleútjáras6; ekkor próbálja rávenni egy általa alapítandó új hírlap szerkesztésére.

Elsó találkozásukról Kemény így számol be Naplójában: „Õ kezem megszorította s kezei közül ki nem bocsátván monda: rég vágytam önnel megösmerkedni. Munkáját olvastam. Sokszor gondolkoztam: fölmaradhat-é fajunk? Van-é jövendōje a magyarnak? S higgye el ön, hogy fajunk egykori fölvirágzása iránt kevés ok gyổzhetett volna inkább meg, mint az ön könyve, mint az, hogy nálunk most ilyszerü politikai írók támadhatnak. Találkozzunk együtt többször, úgy is reméllem, rövid idổn szorosabb viszony fog egymáshoz kötni." 57 A szoros viszony azonban nem jött létre. Kemény Széchenyitôl is, Kossuthtól is igyekszik bizonyos távolságot tartani, s a centralisták (Eötvös József, Csengery Antal) társaságában találja meg azt a szellemi miliổt, amely leginkább megegyezik a magában már kialakított társadalomfilozófiával.

A korszak egész atmoszférájára jellemzổ, hogy a császári titkosszolgálat fontosnak tartotta nyomon követni Széchenyi és Kemény találkozását, és megpróbált pontosan tájékozódni közös terveikrớl. Az 1846. június 27-én kelt rendốri jelentés szerint Kemény egyelỡre nem fogadta el a felkínált szerkesztôi állást, „csak megígérte, hogy cikkeket küld Széchenyinek annak megmutatására, milyen szellemben akarja vállalni a megbízást. Így lehet, hogy megegyeznek".s8

A reformkori erdélyi publicisztikában tisztes rangot kivívó Teleki Domokos 1831-ben a pesti tudományegyetemen folytatott jogi tanulmányokat, $s$ ott nemcsak mũveivel, hanem magával Széchenyivel is személyesen megismerkedett. „Ezen két év alatt - írja jegyzeteiben tanulmányai idejérổ - Magyarország legbecsületesehb államférfiainak társasága, kik közül Széchenyi, el merem mondani, pártfogására, szívességére, sổ bizalmára is méltatott, bizonyára a legdöntôbb hatással voltak egész életemre. "\$ง

Teleki ismerte a személyiség és a történelem között fennálló valódi összefüggéseket, $s$ ezért nem Széchenyi fellépésével magyarázza a magyar reformkor kezdetét, hanem a XIX. század húszas és harmincas éveinek történelmi mozgásából vezeti le a Széchenyijelenséget. Nem félt használni a „fejlổés” fogalmát, sốt egyenesen azt állíța, hogy „a fejlởés gyakorolta magára Széchenyire is a legnagyobb hatást". Megállapítja róla, hogy "világismerettel" s „hazája és nemzete jellemének és szükségeinek" számbavételével válogatta meg azokat az eszközöket, melyekkel a mozdulatlanságból kibillenô társadalomban célirányt szabott a közösségi érdekeket szolgáló egyéni cselekedeteknek.

Teleki Széchenyiben az írót, a szónokot és a közéletben forgolódó közéleti embert egyaránt nagyra értékeli: „bátran elmondhatjuk, hogy Széchenyi remekül írt. de még remekebbül beszélt; s mi vala ennél még remekebb?... Nemde Széchenyi tette, Széchenyi müvei...?"

A Széchenyi halálakor megnyilatkozó országos részvét bizonyítja, hogy Erdély mennyire magához ölelte a nagy férfiút, ahogy akkoriban mondták, „a nemes grófot”. A városok nagy templomait zsúfolásig töltötték meg a gyászistentiszteletekre összesereglett hívők, s ott a felekezetek legiobb szónokai méltatták az elhunyt érdemeit. Most nem azt

55 Gróf Széchenyi István levelei III. Szerk. Majláth Béla. Bp. 1891. 244.

56 1846. mäjus 6-án hívja meg Széchenyi Kovảes Lajost és Kemény Zsigmondot. Uo. 397.

57 Kemény Zsigmond naplója. Szerk. Benkõ Samu. Buk. 1966. 151.

58 Széchenyi-Kossuth idézett hírlapi vitája II. Bp. 1930. 1038-1039

\$9 Szinnyei József: Magyar írók élete és munkái XIII. Bp. 1909. 1399-1402.

60 Teleki Domokos: Emlékbeszéd grớf Széchenyi István felett. Kvár 1860. 4. 
kívánom kiemelni, hogy ezeken a megemlékezésekben ott voltak az erdélyi közélet nagyjai - Mikó Imrétôl Andrei Şagunáig —, hanem azt találom jellemzổnek, hogy az egyszerủ emberek ebben az arisztokratában a maguk fiát gyászolták meg. A hatalom nem rendelt el hivatalos gyászt, de például a kolozsvári Szent Mihály-templomban tartott rekviem idején - noha éppen hetivásár napja volt - „egyszerre minden bolt bezáratott, minden üzlet innepelt szomorü gyásszal, nagy és mély benyomású ünnepé tette a hétköznapot a hazafi fájdalmon alapult önkéntes akarat! Egy ember gyászravatala körül égtek a mécsek, ki annyira százada felett állt, hogy szelleme elôtt az egész nemzet leborul, s férfi és nô, aggastyán és fiatal Magurától a Tarkóig siratja és gyászolja ốt gyászfátyollal és nemzeti és hazafi bánattal". ${ }^{61} \mathrm{~S}$ talán még ennél is meghatóbb Bartalus József református lelkipásztor beszámolója, mely egy kis Belsô-Szolnok megyei falu gyászünnepélyérôl tudósít: „Mi is Bálványosváralján háromféle hitủ lelkészek halotti imát mondottunk a nagy férfi végtiszteletére; a görög egyesült hitũ lelkész által magyar és román nyelven elszavalt emlékbeszéd által érezhetõen volt fölterjesztve a tudatlanabb népelem elốtt, hogy mit vesztett egy állam közösen, és üdvös boldogságára nézt, egy derék tag elhunytával!... Kevés ugyan a mit tehetünk társaskörünkben, de vallásosság $\mathrm{s}$ testvériség a fôindok - ti. rokonkebellel simult helységünkbeni három rendszer $s$ észletekben különbözố felekezet s népelem egymáshoz."62

Rendre megemlékeznek Széchenyirôl mindazok az intézmények, melyeknek tagiai, illetôleg vezetổi úgy érzik, hogy tôle kapták a biztatást szervezkedésükhöz és munkálkodásukhoz. Különösen két testület, az Erdélyi Gazdasági Egyesület és az Erdélyi Múzeum-Egyesület vezetôi hangsúlyozzák gyászünnepélyeiken, hogy Széchenyi volt az, „akinek hatályos szózata legelébb adott életet a nemzetben az egyesülés üdvös eszméjének".63

A nemzeti gyászban megszólaló költôk is - élükön Arany Jánossal - azt tudatosítják, hogy „nem hal meg az, ki milliókra költi dús élte kincsét”.64 A másik költõ, Tompa Mihály a gyász nehéz perceiben azon töpreng, hogy ki lehetne az a férfiú, aki méltóképpen az eltávozott helyére léphetne. Ö az erdélyi múvelốdési intézmények, az Erdélyi Gazdasági Egyesület és az Erdélyi Múzeum-Egyesület alapítójában, Mikó Imrében találja meg a méltó utódot, $s$ arra biztața:

Ragadd gyorsan, Erdély Széchenyie,

Ragadd kezedbe a szent lobogót!

Elôl s fenn kell annak lebegnie,

Mint amidốn az ô kezében volt!6s

Tompa Mihály szép költôii lẻleményének mélységes tisztelete mellett - de némileg vitába szállva vele - hadd szögezzem le, hogy Erdély Széchenyije mégiscsak maga Széchenyi István volt, s ô is marad!

61 Gróf Széchenyi István requiemje. Kolozsvári Közlöny (a továbbiakban: KK) 1860. április 29.

62 KK. 1860 . máius 31.

63 KK. 1860 . június 3.

64 Arany János: Széchenyi emlékezete.

65 Tompa Mihály: Gróf Mikó Inréhez. 